\title{
Influence of glutamine on transient and stable recombinant protein production in $\mathrm{CHO}$ and HEK- 293 cells
}

\author{
Yashas Rajendra, Divor Kiseljak, Lucia Baldi, David L Hacker, Florian M Wurm \\ From 22nd European Society for Animal Cell Technology (ESACT) Meeting on Cell Based Technologies \\ Vienna, Austria. 15-18 May 2011
}

\section{Background}

Glutamine is an essential component in culture media for most of the mammalian cell lines. It is often used as an alternative source of energy by cells, along with glucose. Glutamine metabolism induces ammonia accumulation in cell culture. Elevated ammonia concentration above $2 \mathrm{mM}$ has been shown to have negative impact on both cell growth and recombinant protein productivity [1-4]. In this study we investigated the effects of decreased glutamine concentration in the medium for CHO-DG44 and HEK-293E cells during transient gene expression (TGE). The rationale was to reduce ammonia accumulation in the culture, and consequently, improve cell viability and recombinant protein productivity.

\section{Materials and methods CHO-DG44 transfection}

The cells were centrifuged and resuspended in Pro$\mathrm{CHO} 5$ medium (Lonza, Verviers, Belgium) at a density of $5 \times 10^{6}$ cells $/ \mathrm{mL}$ in orbitally shaken $250 \mathrm{ml}$ glass bottles. Each transfection was performed in $100 \mathrm{~mL}$ of culture using $0.6 \mu \mathrm{g}$ of plasmid DNA and $3.0 \mu \mathrm{g}$ of linear $25 \mathrm{kDa}$ polyethyleneimine (PEI, Polysciences, Eppelheim, Germany; pH 7) per million cells. The transfected cultures were incubated at $31{ }^{\circ} \mathrm{C}$ in $5 \% \mathrm{CO} 2$ and $85 \%$ humidity with agitation at $120 \mathrm{rpm}$.

\section{HEK-293E transfection}

The cells were centrifuged and resuspended at density of $20 \times 10^{6}$ cells $/ \mathrm{mL}$ in RPMI 1640 medium. Each transfection was performed in $100 \mathrm{~mL}$ of culture using $1.5 \mu \mathrm{g}$ of

\footnotetext{
* Correspondence: florian.wurm@epfl.ch

Laboratory for Cellular Biotechnology (LBTC), École Polytechnique Fédéral de Lausanne (EPFL), CH-1015 Lausanne, Switzerland

Full list of author information is available at the end of the article
}

plasmid DNA and $3.0 \mu \mathrm{g}$ of linear $25 \mathrm{kDa}$ PEI per $10^{6}$ cells. Three hours post-transfection, cells were diluted with Ex-Cell293 medium (Sigma, Saint-Louis, USA) to a density of $2 \times 10^{6}$ cells $/ \mathrm{mL}$, and valproic acid was added to a final concentration of $3.75 \mathrm{mM}$. The transfected cultures were incubated at $37{ }^{\circ} \mathrm{C}$ in $5 \% \mathrm{CO}_{2}$ and $85 \%$ humidity with agitation at $120 \mathrm{rpm}$.

\section{Stable Clone and Pool}

A cell line and cell pool expressing anti-Rhesus IgG was kindly provided by Tatiana Benavides from our lab. Cell line was established by transfection of plasmid containing both light and heavy chain into CHO-DG44 cells, followed by flow cytometer sorting and limiting dilution. Cell pool was established by transfection of plasmid containing both light and heavy chain into CHO-DG44 cells, followed by selection under puromycin for two weeks.

\section{Metabolic analytes and IgG levels}

The levels of glucose, glutamine, ammonium, and lactate were determined with a BioProfile 200 Bioanalyzer (Nova Biomedical Corp., Waltham, MA). The IgG concentration in the culture medium was determined by sandwich ELISA as previously described [5].

\section{Results}

Low glutamine concentration improved transient IgG production

Different concentrations of free glutamine in medium, ranging from $0 \mathrm{mM}$ to $6 \mathrm{mM}$ were tested. Both cell lines showed improved production of IgG with a reduced glutamine concentration (Fig. 1 panel A). The optimal concentration of glutamine in terms of IgG production was $2 \mathrm{mM}$ for CHO-DG44 cells and $0 \mathrm{mM}$ for 

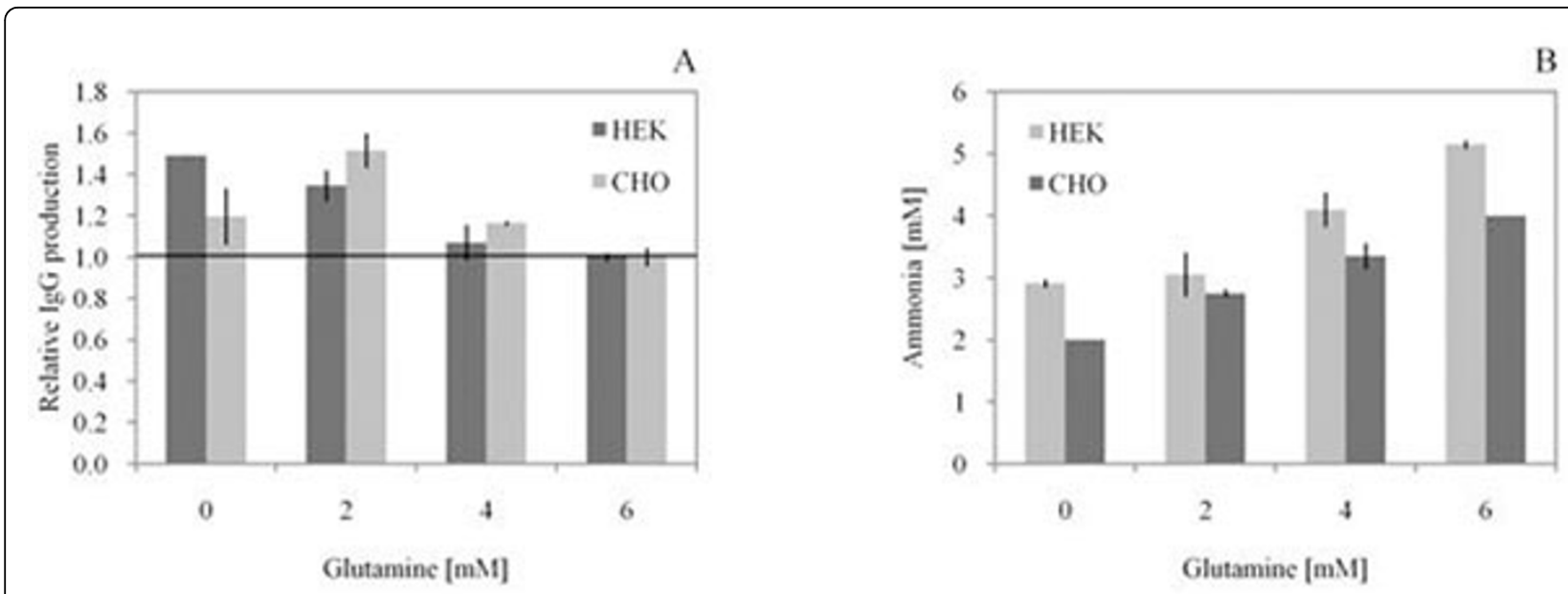

Figure 1 Effect of glutamine concentration on relative A) IgG production and B) Ammonia accumulation in CHO-DG44 cells and HEK-293E cells under transient transfection conditions on day 7 .

HEK-293E cells. We observed a 50\% improvement in IgG production for both CHO-DG44 and HEK293 cells. We did not observe a significant difference on cell density or viability between the tested concentrations of glutamine for both CHO-DG44 and HEK293 cells during the entire course of the culture (data not shown).

Higher initial concentration of glutamine resulted in higher concentration of ammonia, up to $5 \mathrm{mM}$ for the highest glutamine concentration tested (Fig 1 panel $\mathrm{B}$ ).

Lactate accumulation in both CHO-DG44 and HEK293E cells was observed during the initial phase of the cultures, while the cells were actively growing. In CHODG44 cells, consumption of lactate started immediately after its accumulation. In HEK-293E cells, lactate levels remained either at a constant level or, in the absence of glutamine, continued to increase over the entire culture (data not shown). Glucose and glutamine consumption rate remained unaffected under all the conditions tested.

\section{Lower initial glutamine concentration improved stable IgG production in growth-arrested stable CHO-DG44 cells and pools}

A stable cell clone and cell pool of CHO-DG44 cells expressing IgG were cultivated in the presence of different glutamine concentrations under mild hypothermia conditions $\left(31^{\circ} \mathrm{C}\right)$. Both the clone and the cell pool showed improved production of IgG with reduction in glutamine concentration. The IgG titers were approximately $80 \%$ higher for the clone and $60 \%$ higher for the pool at $0 \mathrm{mM}$ glutamine, compared to titers obtained with $6 \mathrm{mM}$ glutamine (data not shown).

\section{Conclusions}

The effects of different concentrations of glutamine on IgG production in growth arrested cells were investigated. Recently published results show that $\mathrm{CHO}-$ DG44 cells are arrested in G1 phase of the cell cycle under mild hypothermia at $31^{\circ} \mathrm{C}$ [6]. For HEK-293E cells growth arrest was induced with VPA [7]. We conclude that a lower glutamine concentration results in improved transient antibody titers in CHO-DG44 and HEK-293E cells mainly due to lower accumulation of ammonia in the culture, which has previously been shown to have a negative impact on cellular productivity [1-4]. Glutamine reduction also had a positive impact on recombinant IgG production in a stable clone and a pool of recombinant CHO-DG44 cells at $31^{\circ} \mathrm{C}$. These data suggest that this strategy may be successful in both transient and stable gene expression processes under conditions of growth arrest.

\section{Acknowledgments}

We thank Tatiana Benavides and Mattia Matasci for providing the $\mathrm{CHO}$ clone and pool. Part of this work was supported by the Swiss Innovation Promotion Agency KTI/CTI of the Swiss Federal Department of Economic Affairs (n. 10203.1PFLS-LS) under a collaboration with ExcellGene SA (Switzerland).

\section{Published: 22 November 2011}

\section{References}

1. Canning WM, Fields BN: Ammonium chloride prevents lytic growth of reovirus and helps to establish persistent infection in mouse $\mathrm{L}$ cells. Science 1983, 219:987-988.

2. Hansen HA, Emborg C: Influence of ammonium on growth, metabolism, and productivity of a continuous suspension Chinese hamster ovary cell culture. Biotechnol Prog 1994, 10:121-124.

3. Ito M, McLimans WF: Ammonia inhibition of interferon synthesis. Cell Biol Int Rep 1981, 5:661-666.

4. Reuveny $S$, Velez D, Macmillan JD, Miller L: Factors affecting cell growth and monoclonal antibody production in stirred reactors. I Immunol Methods 1986, 86:53-59.

5. Meissner P, Pick H, Kulangara A, Chatellard P, Friedrich K, Wurm FM: Transient gene expression: recombinant protein production with 
suspension-adapted HEK293-EBNA cells. Biotechnol Bioeng 2001,

75:197-203.

6. Wulhfard S, Tissot S, Bouchet S, Cevey J, De Jesus M, Hacker DL, Wurm FM:

Mild hypothermia improves transient gene expression yields several fold in Chinese hamster ovary cells. Biotechnol Prog 2008, 24:458-465.

7. Greenblatt DY, Vaccaro AM, Jaskula-Sztul R, Ning L, Haymart M, Kunnimalaiyaan $\mathrm{M}$, Chen H: Valproic acid activates notch-1 signaling and regulates the neuroendocrine phenotype in carcinoid cancer cells. Oncologist 2007, 12:942-951.

doi:10.1186/1753-6561-5-S8-P35

Cite this article as: Rajendra et al: Influence of glutamine on transient and stable recombinant protein production in CHO and HEK-293 cells. BMC Proceedings 2011 5(Suppl 8):P35.

Submit your next manuscript to BioMed Central and take full advantage of:

- Convenient online submission

- Thorough peer review

- No space constraints or color figure charges

- Immediate publication on acceptance

- Inclusion in PubMed, CAS, Scopus and Google Scholar

- Research which is freely available for redistribution

Submit your manuscript at www.biomedcentral.com/submit 